\title{
BRPKM
}

Buletin Riset Psikologi dan Kesehatan Mental

http://e-journal.unair.ac.id/index.php/BRPKM

e-ISSN: 2776-1851

ARTIKEL PENELITIAN

\section{Gambaran Koping terhadap Stres Masa Isolasi pada Pasien Covid-19 Usia Dewasa Awal}

\author{
FARAH ADILAH NURUL MAULIDYA \& WIWIN HENDRIANI* \\ Fakultas Psikologi Universitas Airlangga
}

\begin{abstract}
ABSTRAK
Penelitian ini bertujuan untuk mengetahui gambaran koping stres yang dilakukan oleh pasien Covid-19 selama menjalani isolasi. Terdapat beberapa situasi stres yang menuntut mereka untuk melakukan koping stres. Koping merupakan usaha yang didalamnya terdapat proses kognitif dan perilaku untuk mengelola, mengatasi, dan meminimalisir tuntutan-tuntutan internal dan eksternal yang dinilai melebihi dan dapat membebani kemampuan individu. Terdapat dua jenis koping, yaitu problem focused coping dan emotional focused coping. Penelitian ini menggunakan metode kualitatif dengan pendekatan studi kasus instrinsik. Penggalian data melalui wawacara dengan pasien Covid-19 yang telah mendapatkan hasil negatif serta adanya orang terdekat dari masing-masing partisipan. Hasil penelitian ini menunjukkan bahwa ketiga partisipan menggunakan kedua jenis koping dan disesuaikan dengan stres yang dialami. Peneliti menemukan bahwa terdapat faktor eksternal maupun internal individu yang mempengaruhi perbedaan dalam penggunaan koping sehingga tiap individu akan menggunakan koping dengan kemampuannya masing-masing.
\end{abstract}

Kata kunci: dewasa awal, isolasi covid-19, koping

\begin{abstract}
This study aims to determine the description of coping stress performed by Covid-19 patients during isolation. There are several stressful situations that requires them to adopt coping stress. Coping is an effort in which there are cognitive and behavioral processes to manage, overcome, and minimize internal and external demands that are considered to exceed and can burden the individual's ability. There are two types of coping, problem focused coping and emotional focused coping. This research used a qualitative method with an intrinsic case study approach. Data assessment through in-depth interview with Covid-19 patients who had negative results and the significant other. As a result, three participants used both types of coping and adjust to their perceived stress. Researcher found there are external and internal factors that influence the differences to used coping, so that each individual will cope according to their own abilities.
\end{abstract}

Keywords: coping, covid-19 isolation, early adult

Buletin Penelitian Psikologi dan Kesehatan Mental (BRPKM), 2021, Vol. 1(2), 1263-1274

*Alamat korespondensi: Fakultas Psikologi Universitas Airlangga, Kampus B Universitas Airlangga Jalan Airlangga 4-6 Surabaya 60286. Surel: wiwin.hendriani@psikologi.unair.ac.id 
sehingga penggunaan, distribusi, reproduksi dalam media apapun atas artikel ini tidak dibatasi, selama sumber aslinya disitir dengan baik.

\section{PEN D A H U L U A N}

Coronavirus disease atau Covid-19 merupakan penyakit yang terjadi pada sistem pernapasan yang dapat berdampak hingga kematian, virus ini berasal dari golongan SARS-CoV-2 (Severe Acute Respiratory Syndrome Coronavirus 2). WHO sebagai organisasi kesehatan dunia telah mengonfirmasi bahwa virus ini dapat ditularkan saat individu melakukan kontak fisik dengan individu yang sudah terinfeksi atau menghirup udara yang telah terkontaminasi dengan droplet yang dihasilkan oleh penderita ketika batuk atau bersin. Tidak hanya memberikan dampak terhadap kesehatan fisik, wabah ini telah memberikan dampak yang luas pada berbagai aspek kehidupan baik aspek ekonomi, politik, sosial hingga psikologis individu. Dampak pada psikologis individu seperti cenderung mengalami ketakutan akan tertular virus, ketakutan akan gejala berat atau sekarat, dan memiliki stereotip terhadap orang lain (Handayani dkk., 2020). Dampak serupa juga dirasakan oleh pasien yang terinfeksi virus korona. Pasien yang terinfeksi virus korona diharuskan menjalani isolasi untuk mendapatkan perawatan serta mencegah proses penyebaran virus. Pasien akan menjalani isolasi baik di rumah sakit, wisma yang disediakan oleh pemerintah atau isolasi mandiri di rumah. Perawatan terhadap penyakit ini berbeda dengan perawatan penyakit lainnya karena adanya protokol kesehatan khusus seperti penggunaan alat-alat pelindung diri yang digunakan dokter, perawat, atau tenaga medis lainnya saat melakukan kontak dengan pasien. Selain itu, pasien tidak diperbolehkan menerima kunjungan serta adanya keterbatasan dalam beraktivitas.

Pasien yang berada dalam situasi isolasi akan mengalami kesepian (Zandifar dkk., 2020). Hal tersebut dikarenakan situasi isolasi mengharuskan adanya perpisahan dengan orang yang dicintai atau keluarga (Brooks dkk., 2020). Zandifar dkk. (2020) juga menyatakan konsekuensi mematikan dari Covid-19 dapat menjadi suatu tekanan bagi pasien saat menjalani masa isolasi. Selain itu, tekanan yang dialami pasien tidak hanya dari diri individu itu sendiri, tetapi juga berasal dari lingkungan disekitarnya (Nurjanah, 2020). Pasien yang dinyatakan terinfeksi virus korona dan wajib untuk menjalankan isolasi merasa tertekan dengan adanya stigma dan diskriminasi dari masyarakat (Zandifar dkk., 2020). Aslamiyah \& Nurhayati (2021) melakukan penelitian yang menemukan adanya pasien yang mengalami kesulitan untuk tidur dikarenakan memikirkan banyak hal seperti bagaimana kondisi kesehatan dirinya serta keluarga yang ditinggalkan di rumah.

Dilansir oleh media online, SATGAS percepatan penanganan Covid-19 menyatakan bahwa dari kelompok usia produktif tercatat sekitar 55 hingga 70\% dari total pasien yang positif terinfeksi virus korona (Antara, 2020). Selain itu, juga tercatat data Kementerian Kesehatan per 9 Februari 2021 angka kematian pada usia 19 sampai 30 tahun sebesar 4,8\% atau sekitar 55.971 orang (Supriatin, 2021). Pada kelompok usia produktif ini, termasuk individu dengan usia dewasa awal yang terinfeksi virus korona. Menurut Erikson, tokoh yang mengembangkan teori psikososial, dewasa awal termasuk dalam tahapan intimacy vs isolation. Intimacy dianggap sebagai proses individu menemukan dirinya dengan peleburan diri di dalam orang lain (Santrock, 2012). Namun, pasien dewasa awal yang menjalani isolasi mengalami keterbatasan dalam menjalin relasi intim secara langsung dengan lingkungannya serta adanya stigma penyakit dari masyarakat. Dengan demikian, menjadi suatu tantangan perkembangan bagi pasien dewasa awal dan dari peristiwa tersebut dapat menyebabkan individu mengalami isolation dan berdampak pada sikap ketidakpercayaan dengan orang lain (Santrock, 2012). Selain itu, pada masa ini individu dengan usia sekitar 20 tahun mulai mengalami quarter life crisis, perasaan khawatir atas 
ketidakpastian terkait kehidupan mendatang seperti permasalahan relasi, karir, maupun kehidupan sosialnya (Fisher dalam Rahmania \& Tasaufi, 2020). Dimana menjadi suatu bentuk kekhawatiran baru yang harus dialami pasien dengan tidak adanya kepastian mengenai masa durasi isolasi.

Berbagai tekanan yang dirasakan oleh pasien dapat mempengaruhi kondisi kesehatan seperti menurunnya kemampuan sistem imunitas tubuh (Taylor, 2015). Sedangkan untuk melawan penyakit ini dibutuhkan imunitas tubuh yang baik (Abdillah, 2020). Adapun tekanan-tekanan yang ada secara kolektif dapat memberikan trauma baru atau retraumatisasi dalam rentang kehidupan (Browne dkk., 2020). Bo dan rekan-rekannya (2021) menyatakan bahwa terdapat prevalensi gejala Post-Traumatic Stress Disorder (PTSD) yang signifikan terjadi pada pasien sebesar 96,2\% dari 730 pasien mengalami gejala trauma pasca stres isolasi Covid-19 dan trauma ini dapat berdampak negatif seperti kualitas hidup yang rendah dan terganggunya kinerja kerja. Maka dari itu, diperlukan koping yang baik untuk meminimalisir tekanan yang muncul.

Individu memerlukan koping yang baik agar dapat beradaptasi dengan transisi yang dihadapi dan terhindar dari perilaku maladaptif serta dampak negatif terkait psikologis dan sosial (Steinhardt \& Dolbier dalam Mayordomo-Rodríguez dkk., 2014). Lazarus \& Folkman (1984) menjelaskan bahwa koping merupakan usaha yang didalamnya terdapat proses kognitif dan perilaku untuk mengelola, mengatasi, dan meminimalisir tuntutan-tuntutan internal dan eksternal yang dinilai melebihi dan dapat membebani kemampuan dari seorang individu dan membaginya menjadi dua jenis, yaitu problem focused coping dan emotional focused coping. Problem focused coping merupakan koping yang digunakan oleh seorang individu untuk menyelesaikan permasalahan yang ada dengan cara melakukan alternatif tindakan, serta mencari informasi mengenai masalah yang sedang dihadapi. Upaya yang dilakukan dalam problem focused coping antara lain confrontative coping, planful problem solving, dan seeking social support. Sedangkan, emotional focused coping merupakan koping yang digunakan oleh seorang individu untuk membantu mengatur kondisi emosional diri dalam menyesuaikan pada dampak dari permasalahan yang ada. Upaya yang dilakukan dalam emotional focused coping adalah self-control, positive reappraisal, accepting responsibility serta adanya upaya yang bersifat negatif seperti distancing dan escape/avoidance.

Ditemukan sejumlah diantaranya pasien Covid-19 dalam menjalani isolasi, tidak dapat mengatasi tekanan sehingga mereka memunculkan perilaku negatif yang dapat membahayakan dirinya maupun orang lain seperti berteriak, melukai dirinya sendiri, menyerang petugas medis, menghancurkan properti yang ada di rumah sakit atau tempat isolasi, atau mencoba melarikan diri keluar jendela (Abdullah, 2020). Bahkan terdapat kasus seorang pria muda terinfeksi Covid-19 melakukan percobaan bunuh diri dari lantai 3 bangsal rumah sakit (Epstein dkk., 2020).

Sun dan rekan-rekannya (2021) melakukan penelitian bahwa terdapat pasien yang sudah berupaya melakukan koping dengan baik, diantaranya menggunakan problem focused coping yaitu planful problem solving dan seeking social support. Hal ini dikarenakan pasien menetapkan tujuan yang dapat dicapainya dalam kegiatan sehari-hari serta aktif meminta pertolongan kepada psikolog untuk melakukan konsultasi melalui telepon. Selain itu, pasien juga menggunakan koping escape/avoidance dengan mengalihkan perhatiannya pada permainan online atau menonton video yang membuatnya tertawa. Di Indonesia, dilakukan penelitian dengan mewawancarai 3 pasien Covid-19 yang tidak dapat menerima keadaan yang dialaminya. Kemudian melakukan koping dengan baik dan pada akhirnya 3 pasien tersebut beranggapan bahwa apa yang terjadi merupakan ujian serta memasrahkan segalanya kepada Tuhan (Febriani, 2020). 
Pentingnya melakukan koping yang baik bagi pasien saat menjalani isolasi bagi dampak psikologis jangka panjang pada pasien, serta masih kurangnya penelitian terkait koping pasien di Indonesia, menjadi dasar peneliti melakukan penelitian terkait gambaran koping terhadap stres masa isolasi pada pasien Covid-19 dewasa awal yang telah mendapatkan hasil non-reaktif dan sudah mulai melanjutkan kegiatan sehari-harinya.

\section{Desain Penelitian}

\section{E T ODE}

Penelitian ini menggunakan metode kualitatif dengan pendekatan studi kasus instrumental dikarenakan berawal dari pemilihan suatu fenomena yang kemudian peneliti mengaitkannya dengan teori yang sesuai sebagai kerangka berpikir dalam melakukan pendalaman, sesuai dengan tujuan penelitian yaitu untuk mengetahui lebih dalam terkait gambaran koping stres yang dilakukan oleh pasien Covid-19 selama menjalani isolasi. Pada penelitian ini menggunakan teknik analisis tematik theory-driven dengan menganalisis pola-pola atau tema-tema yang telah ditentukan dari teori atau penelitian-penelitian sebelumnya dan teknik pemantapan kredibilitas dengan triangulasi data, yaitu wawancara dengan significant other dan member-check (Boyatzis, 1998 dalam Poerwandari, 2013).

\section{Partisipan}

Partisipan penelitian ini dipilih secara purposif yang merupakan teknik mencari partisipan penelitian sesuai dengan kriteria tertentu yang sudah ditentukan (Neuman, 2007). Kriteria yang digunakan untuk mendapatkan partisipan diantaranya adalah individu usia dewasa awal yaitu berusia 18-25 tahun serta pernah menjalani masa isolasi Covid-19 (Arnett, 2006 dalam Santrock, 2012). Selain itu, terdapat informed consent sebelum dilakukan penggalian data. Didapatkan tiga partisipan yang berinisial MB (20) yang telah menjalani isolasi selama 2 bulan serta significant other N (21), AH (24) yang telah menjalani isolasi selama 21 hari serta significant other B (23), dan ZA (24) yang telah menjalani isolasi selama 11 hari serta significant other L (24).

\section{Strategi Pengumpulan Data}

Teknik penggalian data menggunakan wawancara semi-terstruktur dengan pedoman wawancara. Pertanyaan-pertanyaan yang diajukan kepada partisipan berdasarkan pada fokus penelitian kemudian menggunakan in-depth interview untuk memperdalam data yang diperoleh. Penggalian data juga dilakukan dengan orang terdekat partisipan atau significant other yang mengetahui kondisi partisipan selama masa isolasi, hal tersebut dilakukan guna mengelaborasi dan memperkaya data penelitian (Marshall \& Rossman dalam (Poerwandari, 2013). Wawancara dilakukan sebanyak 2 kali pada tiap partisipan dan dengan significant other sebanyak 1 kali. 


\section{a. Partisipan MB}

\section{HAS IL PEN ELIT I A N}

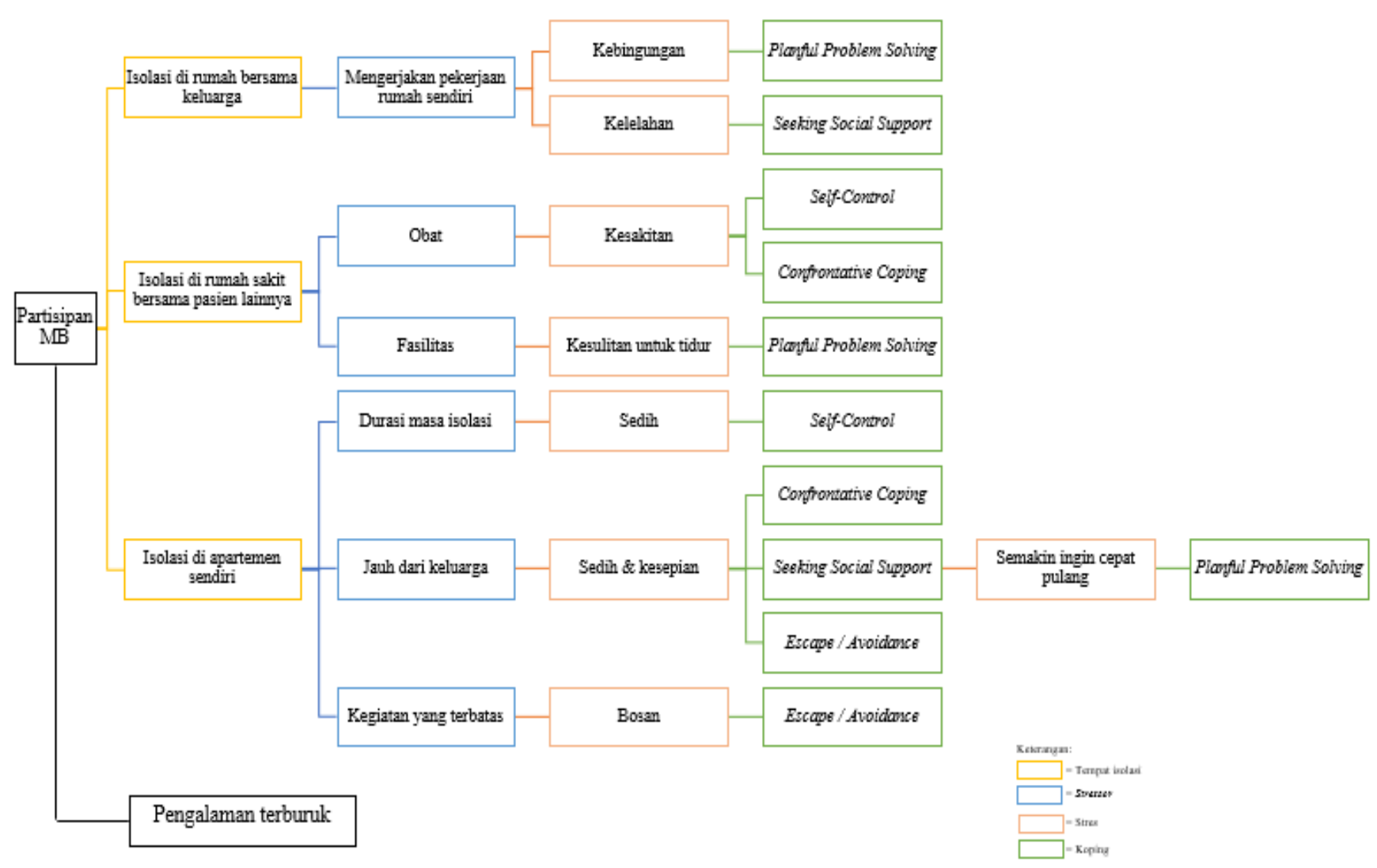

Gambar 1. Hasil Data Partisipan 1

Partisipan MB sempat menjalani isolasi di rumah, selama isolasi ia mendapatkan tanggung jawab dalam mengelola pekerjaan rumah. Hal tersebut membuatnya kebingungan, ia pun melakukan planful problem solving dengan membuat jadwal kegiatan. Walaupun ia sudah melakukan koping dalam mengatasi pekerjaan rumah, hal tersebut memunculkan tekanan lain yaitu ia merasa kelelahan mengerjakan pekerjaan rumah sendiri dengan kondisi kesehatannya yang pada saat itu kurang baik, sehingga ia juga melakukan seeking social support dengan menceritakan kondisinya kepada teman dekatnya. Ia juga mengeluhkan kapan situasi tersebut selesai.

Selanjutnya MB menjalani situasi isolasi di rumah sakit, ia mendapatkan pengobatan secara injection hal tersebut memicu tekanan fisik. MB pada awalnya dapat melakukan self-control dengan menolerir rasa sakit dari pengobatan tersebut, namun semakin lama ia semakin merasa kesakitan dan mengalami pembengkakan akibat perpindahan suntikan dari injection tersebut. Akhirnya ia pun melakukan confrontative coping dengan berusaha keluar dari keadaan yang membuatnya sakit, meminta suster untuk mengganti obat tersebut. Selain permasalahan obat, MB mengalami kesulitan tidur karena harus berbagi kamar tidur dengan pasien yang lain serta kasur yang tidak nyaman. MB mengatasinya dengan melakukan planful problem solving, memikirkan jika ia tidak segera tidur atau begadang dalam kondisi

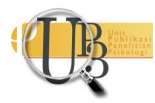


kesehatannya yang tidak baik akan berdampak pada lamanya proses penyembuhan, ia pun segera memaksakan diri untuk tidur.

Terakhir MB menjalani isolasi di apartemen seorang diri. Ia merasa bosan dan kesepian karena tidak adanya teman dan jauh dari keluarga. Dalam mengatasi kesepiannya, ia melakukan confrontative coping dengan menelpon keluarganya setiap hari serta seeking support social dengan menceritakan situasi isolasinya. Setelah melakukan hal tersebut, MB semakin merasakan sedih dan ingin cepat pulang. Keinginannya untuk cepat pulang ia atasi dengan planful problem solving, ia tidak ingin berlama-lama di tempat isolasi sehingga ia harus makan yang banyak dan rutin meminum obat. Selain itu, MB juga dihadapkan dengan situasi yang membosankan karena ia tidak dapat melakukan aktivitas selain di dalam kamar. Ia mencoba melakukan escape/avoidance dengan mengerjakan tugas yang dapat mengalihkan pikirannya mengenai situasi yang membosankan di apartemen dan merasa dapat memanfaatkan waktu sebaik mungkin.

\section{b. Partisipan $\mathrm{AH}$}

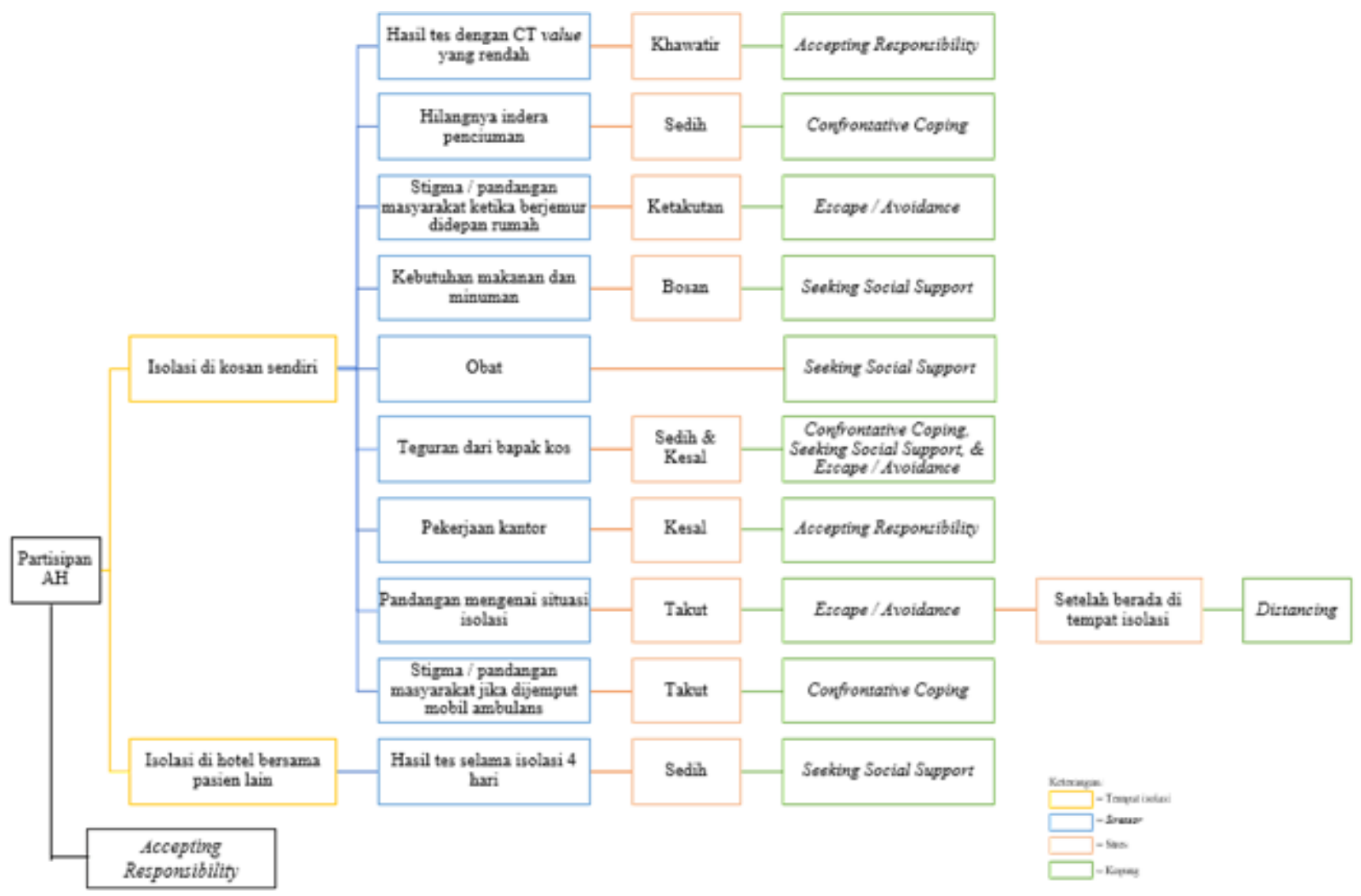

Gambar 2. Hasil Data Partisipan 2

Saat menjalani isolasi, partisipan AH memiliki sebuah tanggung jawab atas pekerjaan kantor. Hal tersebut membuat AH merasa kesal dengan pihak kantor yang tidak memberikan keringanan pekerjaan kepadanya. Pada akhirnya AH pun melakukan acceptance responsibility, menerima situasi tersebut dan mengerjakannya karena merasa bahwa tugas pekerjaannya tidak dapat dialihkan kepada orang lain. Tidak hanya kesal dengan pihak kantor, AH juga merasa sedih dan kesal dengan perlakuan bapak kos

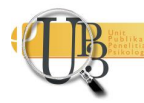


yang menyatakan keberatan $\mathrm{AH}$ menjalani isolasi di kosannya. AH mengatasi permasalahan tersebut dengan tiga cara penyelesaian, pertama ia melakukan seeking social support dengan menceritakan kejadian tersebut kepada Pak RW, kemudian ia melakukan confrontative coping dengan semakin berusaha untuk mendapatkan tempat isolasi, dan juga ia melakukan escape/avoidance karena tidak ingin kejadian tersebut semakin menambah beban pikirannya.

Saat AH menjalani isolasi di kosan, beberapa kebutuhan AH tidak dapat terpenuhi dan untuk memenuhi kebutuhan tersebut mendorong AH melakukan seeking social support. Ia meminta bantuan kepada temannya untuk membelikannya obat-obatan, makanan, minuman, serta perlengkapan seperti masker dan hand sanitizer. Terkait obat-obatan, sebelumnya AH juga menanyakan kepada temannya yang berprofesi sebagai dokter.

Gejala hilangnya indra penciuman menjadi suatu stressor bagi AH. Ia merasa sedih dengan indra penciumannya yang tidak kunjung membaik, sehingga ia pun melakukan confrontative coping. AH berusaha untuk memulihkan penciumannya dengan menghirup bau minyak kayu putih setiap saat dan dari usaha tersebut indra penciuman AH kembali pulih. Selain itu, AH juga disarankan untuk berjemur di halaman depan rumah, ia pun merasa takut dengan pandangan masyarakat sekitar yang melihatnya sedang berjemur. Ia sendiri hanya dapat mengelola perasaan tersebut dengan escape/avoidance atau berjemur sambil menelpon temannya agar tidak terpikirkan oleh pandangan masyarakat dan waktu dapat segera berlalu. Perasaan tersebut muncul juga ketika AH akan dijemput oleh mobil ambulans, penyelesaiannya berbeda dengan saat ia berjemur. Pada permasalahan ini AH langsung melakukan confrontative coping dengan menawarkan diri kepada Pak RW untuk berjalan kaki saja agar ia tidak perlu dijemput mobil ambulans.

Pada hari ke-4 menjalani isolasi diluar, AH menjalani tes untuk mengetahui status dari penyakit. Sebelumnya ia optimis akan mendapatkan hasil yang negatif, akan tetapi hasil yang didapatkan menyatakan bahwa ia masih positif sehingga masih harus menjalani isolasi. AH yang merasa sedih dengan kejadian tersebut, melakukan seeking social support kepada teman-temannya ia menceritakan kondisinya dan mendapatkan dukungan emosional dengan menyemangati AH tetap berusaha untuk sembuh serta dukungan secara instrumental dengan mengirimkan AH makanan agar suasana hatinya membaik. 


\section{c. Partisipan ZA}

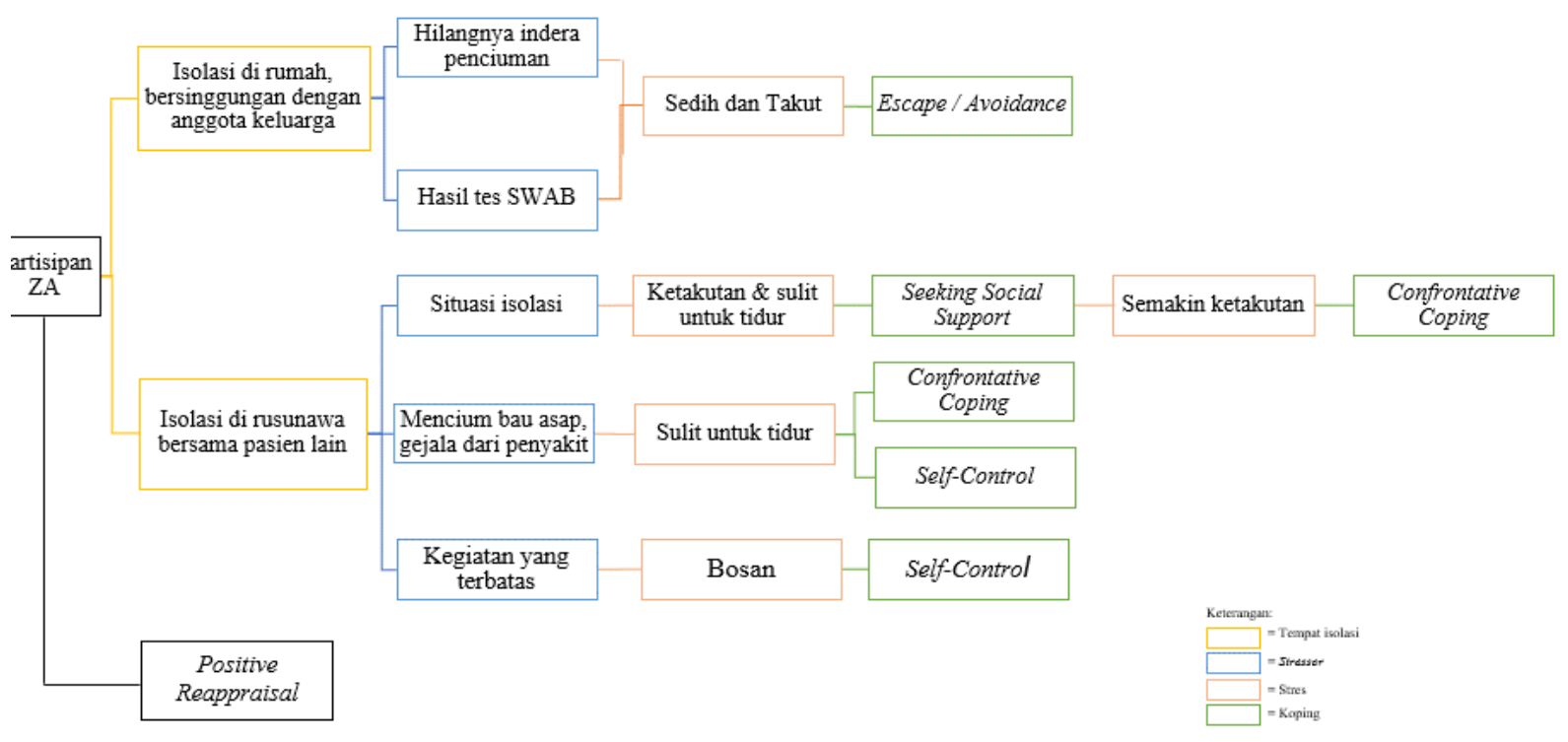

Gambar 3. Hasil Data Partisipan 3

Partisipan ZA juga menanggapi gejala dari penyakit, yaitu hilangnya indra penciuman sebagai suatu stressor. ZA pun mencoba untuk mengalihkan perasaan atau melakukan escape / avoidance dengan menonton drama korea yang dapat membuatnya lupa bahwa ia sedang sakit. Ketika isolasi di rusunawa, ZA mengalami gejala lain terkait pernapasan yang menyesakkan seperti ia sedang menghirup bau asap, hal tersebut membuatnya kesulitan untuk tidur. ZA pun langsung melakukan confrontative coping dengan menutupi hidungnya dan menggunakan masker. Akan tetapi ia merasa masih dapat mencium bau tersebut, sehingga ia semakin merasa sesak. Kemudian ZA mencoba untuk melakukan self-control dengan menenangkan diri agar ia dapat tertidur.

Adapun stressor lain yang membuat ZA merasa kesulitan untuk tidur ketika ia pertama kali menjalani isolasi di rusunawa. Ia merasa bahwa situasi tempat isolasi yang sepi membuatnya merasa ketakutan karena ia sendiri berada dalam 1 unit. Pada saat itu ia melakukan seeking social support dengan menelpon temannya untuk menemaninya sampai ia tertidur dan keesokannya ZA juga menceritakan situasi kepada perawat di rusunawa. Perawat rusunawa berpendapat yang sama dengan ZA dan menambah rasa ketakutan ZA karena menceritakan kejadian seram lainnya. Saat itu ZA sudah memiliki teman sekamar, ia pun berusaha melakukan confrontative coping dengan mengajak teman sekamarnya untuk tidur dalam tempat tidur yang sama.

\section{I S K U S I}

Berdasarkan tahapan perkembangan milik Erikson, ketiga partisipan merupakan individu usia dewasa awal yang sedang berada pada fase intimacy vs isolation. ketiga partisipan merasa lebih baik ketika memiliki teman saat menjalani isolasi. MB menunjukkan kenyamanannya ketika menjalani isolasi di rumah bersama keluarga dan di rumah sakit bersama pasien yang lain, kemudian menunjukkan rasa kesepiannya ketika harus menjalani isolasi di apartemen. Partisipan AH yang mengatakan lebih baik menjalani isolasi di hotel daripada di kosan karena memiliki teman sekamar dalam menjalani

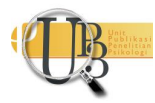


kesehariannya, selain itu ketika temannya telah diperbolehkan untuk pulang ia pun merasakan sedih karena harus menjalani isolasi sendiri. Hal serupa ditunjukkan oleh ZA yang merasa kesepian dan ketakutan ketika pertama kali menjalani isolasi di rusunawa sendiri dan saat sudah memiliki teman sekamar ia pun mengajaknya untuk tidur bersama. Nadi dan teman-temannya (2018) menemukan bahwa individu yang dalam situasi tertentu akan merasa lebih nyaman jika berkumpul bersama dengan individu lain yang bernasib sama dengannya.

Pada saat menjalani masa isolasi dalam kondisi kesehatan yang tidak baik, ketiga partisipan mendapatkan permasalahan atau situasi yang dapat menantang fisik atau psikologis tiap-tiap partisipan. Ketiga partisipan pun berusaha untuk menyesuaikan diri atau menyelesaikan setiap permasalahan yang dihadapinya dengan menggunakan koping tertentu yang menurutnya paling efektif dengan sumber daya yang dimilikinya. Koping yang menjadi tema penelitian ini merupakan bentukbentuk koping yang berasal dari dua jenis koping yaitu problem focused coping dan emotional focused coping (Lazarus \& Folkman, 1984).

Berdasarkan hasil penelitian diatas, dapat diketahui bahwa ketiga partisipan menggunakan koping yang berbeda-beda berdasarkan permasalahan yang dihadapinya, hal tersebut sesuai dengan pernyataan (Evans \& Kim dalam Maryam, 2017). Walaupun adanya kesamaan dalam permasalahan, mereka pun memiliki cara penyelesaiannya masing-masing karena terdapat faktor-faktor yang dapat mempengaruhi individu untuk melakukan koping tidak hanya dari lingkungan atau faktor eksternal, namun adanya faktor dari dalam individu itu sendiri atau faktor internal. Meskipun MB dan ZA merasa sama-sama memiliki kesulitan untuk tidur, namun kedua partisipan ini memiliki cara penyelesaian yang berbeda. Partisipan MB melakukan planful problem solving sedangkan partisipan ZA melakukan confrontative coping. Hal tersebut dilakukan MB karena memiliki kemampuan dalam menyelesaikan masalah dengan menganalisis permasalahan yang ia hadapi kemudian mempertimbangkan hal apa yang harus ia lakukan. Sedangkan ZA melakukan confrontative coping dikarenakan ia memiliki teman sekamar dan berusaha untuk menyegerakan keluar dari situasi yang ia alami.

Saat menghadapi permasalahan yang menyangkut dengan kesejahteraan fisik, ketiga partisipan berusaha melakukan confrontative coping, seperti MB meminta suster untuk mengganti obat yang diberikan, AH mencium bau minyak kayu putih setiap saat untuk memulihkan indra penciumannya, dan ZA berusaha untuk menutupi hidungnya dan menggunakan masker. Kemudian dengan kemampuan sosial yang baik, ketiga partisipan menggunakan seeking social support untuk mendapatkan sebuah bantuan atau dukungan. Dengan demikian, MB menceritakan rasa lelahnya mengerjakan pekerjaan rumah kepada teman dekat, AH menceritakan kesedihannya dengan hasil tes yang masih positif kepada temannya, dan ZA meminta temannya untuk menelpon dan menemaninya agar ia dapat tertidur. Adapun ketiga partisipan mengatasi situasi yang tidak dapat diubahnya, seperti MB bosan dengan situasi isolasi, AH takut dengan pandangan masyarakat sekitar, dan ZA sedih dan takut dengan hasil tesnya, mereka mencoba untuk melakukan escape/avoidance, melakukan aktivitas lain agar dapat mengalihkan perasaan ataupun pikirannya mengenai situasi yang sedang dihadapi.

Selain itu, terkait dengan pemaknaan dari pengalaman isolasi, ketiga partisipan memiliki pemaknaannya masing-masing. MB sendiri memaknai pengalaman isolasinya merupakan pengalaman terburuknya, namun setelah isolasi bagi teman terdekatnya ia masih menjadi sosok yang periang. $\mathrm{AH}$ memaknai pengalaman isolasinya merupakan kesalahan dirinya karena tidak menjaga kesehatan dan menjaga jarak, kemudian setelah isolasi ia dipandang lebih sadar akan adanya protokol kesehatan oleh orang terdekatnya. ZA pun dapat memaknai pengalaman isolasinya secara positif karena ia merasa bahwa diberi waktu untuknya beristirahat dan setelah isolasi pun ia memiliki banyak teman dari media sosialnya. 
Adapun keunikan dari tiap ketiga partisipan. Pada beberapa permasalahan, partisipan MB seringkali melakukan planful problem solving dengan mengkhawatirkan kejadian buruk yang akan terjadi jika ia tidak mengatasinya segera. Hal tersebut dikarenakan MB sedang berada pada masa dewasa awal, dimana individu mengalami ketegangan emosional yang muncul akibat keresahannya terhadap permasalahan (Hurlock, 1997). Bahkan berdasarkan dari wawancara significant other, MB merupakan sosok yang berpikiran negatif dan overthinking mengenai kejadian yang akan dialaminya. Partisipan $\mathrm{AH}$ lebih dominan menggunakan seeking social support dalam menghadapi permasalahan selama masa isolasi. Dari koping tersebut $\mathrm{AH}$ mendapatkan dukungan baik secara emosional yang dapat membuatnya merasa tenang maupun instrumental yang dapat memenuhi kebutuhan AH dalam menjalani masa isolasi. Menurut penggalian data dari significant other AH merupakan sosok yang dapat dengan mudah bergaul sehingga dapat menjadi suatu faktor internal pada AH dalam menggunakan seeking social support. Kemudian partisipan ZA yang dapat memaknai pengalaman isolasinya dengan pandangan yang positif, dimana ia dapat memiliki teman-teman baru berasal dari media sosialnya yang menceritakan terkait pengalamannya selama menjalani isolasi Covid-19.

\section{S I M P U L A N}

Ketiga partisipan yang telah menjalani isolasi Covid-19 di tempat yang berbeda-beda, menerima stressor dan respon yang berbeda pula. Adapun ketiganya mengupayakan koping sebagaimana yang dikemukakan oleh Lazarus \& Folkman (1984) dengan adanya perubahan kognitif dan perilaku sehingga dapat mengelola, mengatasi, dan meminimalisir tekanan atau stres yang muncul, baik menggunakan problem focused coping dan emotional focused coping.

Adanya pengaruh dalam perbedaan penggunaan koping tiap partisipan, yaitu faktor-faktor internal seperti keterampilan dalam memecahkan masalah yang dapat membuat individu untuk terus mencari informasi terkait penyembuhannya, mengidentifikasi permasalahan yang muncul dan dampak dari respon yang diberikan sehingga dapat mempertimbangkan tindakan apa yang tepat untuk mengatasi permasalahan tersebut. Adapun keterampilan sosial yang dimiliki partisipan yaitu sikap yang mudah bergaul sehingga dapat memiliki teman saat menjalani isolasi, berbagi mengenai hal-hal yang dialami partisipan selama isolasi serta mencari dukungan secara psikis maupun materi kepada keluarga dan kerabat dalam menghadapi permasalahan.

Saran untuk penelitian selanjutnya dapat mengembangkan penelitian dengan melakukan screening menggunakan alat ukur stres yang dapat mengetahui kategori atau tingkat stres yang dirasakan pasien selama menjalani isolasi Covid-19 dan dapat mengetahui gambaran koping yang digunakan dari partisipan dengan tingkat stres yang berbeda. Saran untuk keluarga dan kerabat agar dapat memberikan dukungan kepada pasien berupa harapan akan kesembuhan, walaupun dengan keadaan jarak jauh juga dapat menemani atau hadir melalui jaringan telfon atau chat dengan pasien, serta memberikan dukungan materi.

\section{U C AP A N TERIMAKASIH}

Terima kasih kepada partisipan MB, AH, dan ZA yang telah telah bersedia untuk meluangkan waktunya dan berbagi pengalaman terkait topik penelitian. Terima kasih juga kepada orang tua, teman-teman, dan dosen-dosen Fakultas Psikologi Universitas Airlangga atas seluruh dukungan, do'a, serta bantuannya dalam kelancaran penelitian ini. 


\section{DEKLARASI POTENSI TERJADINYAKONFLIK KEPENTINGAN}

Farah Adilah Nurul Maulidya dan Wiwin Hendriani tidak bekerja, menjadi konsultan, memiliki saham, atau menerima dana dari perusahaan atau organisasi manapun yang mungkin akan mengambil untung dari diterbitkannya naskah ini.

\section{PUS TAKA ACUAN}

Abdillah, L. A. (2020). Stigma Terhadap Orang Positif COVID-19 (Stigma on Positive People COVID-19). Yayasan Kita Menulis. https://papers.ssrn.com/sol3/papers.cfm?abstract_id=3582624

Abdullah, I. (2020). COVID-19: Threat and Fear in Indonesia. Psychological Trauma: Theory, Research, Practice, and Policy, 12(5), 488. https://doi.org/10.1037/TRA0000878

Antara. (2020). Satgas Catat Kasus Positif Corona 70 Persen Usia Produktif. 31 Desember. https://www.cnnindonesia.com/nasional/20201230145249-20-587889/satgas-catat-kasuspositif-corona-70-persen-usia-produktif

Aslamiyah, S., \& Nurhayati. (2021). Dampak Covid-19 terhadap Perubahan Psikologis, Sosial dan Ekonomi Pasien Covid-19 di Kelurahan Dendang, Langkat, Sumatera Utara. Jurnal Riset dan Pengabdian Masyarakat, 1(1), 56-69. https://doi.org/10.22373/JRPM.V1I1.664

Bo, H.-X., Li, W., Yang, Y., Wang, Y., Zhang, Q., Cheung, T., Wu, X., \& Xiang, Y.-T. (2021). Posttraumatic stress symptoms and attitude toward crisis mental health services among clinically stable patients with COVID-19 in China. Psychological Medicine, 51(6), 1052-1053. https://doi.org/10.1017/S0033291720000999

Brooks, S. K., Webster, R. K., Smith, L. E., Woodland, L., Wessely, S., Greenberg, N., \& Rubin, G. J. (2020). The psychological impact of quarantine and how to reduce it: rapid review of the evidence. The Lancet, 395(10227), 912-920. https://doi.org/10.1016/S0140-6736(20)30460-8

Browne, D., Roy, S., Phillips, M., Shamon, S., \& Stephenson, M. (2020). Supporting patient and clinician mental health during COVID-19: Via trauma-informed interdisciplinary systems. Canadian Family Physician, 66(7), e190./pmc/articles/PMC7365150/

Epstein, D., Andrawis, W., Lipsky, A. M., Ziad, H. A., \& Matan, M. (2020). Anxiety and Suicidality in a Hospitalized Patient with COVID-19 Infection. European Journal of Case Reports in Internal Medicine, 7(5), 1. https://doi.org/10.12890/2020_001651

Febriani, L. (2020). Gambaran coping stress pada pasien COVID-19. Universitas Negeri Jakarta.

Handayani, R. T., Darmayanti, A. T., \& Atmojo, J. T. (2020). Factors Causing Stress in Health and Community When the Covid-19 Pandemic. 8(3), 353-360. https://doi.org/10.26714/jkj.8.3.2020.353-360

Hurlock, E. B. (1997). Psikologi Perkembangan Suatu Pendekatan Sepanjang Rentang Kehidupan. Jakarta: Erlangga.

Lazarus, R. S., \& Folkman, S. (1984). Stress, Appraisal, and Coping. New York: Springer. https://books.google.co.id/books?hl=en\&lr=\&id=i-

ySQQuUpr8C\&oi=fnd\&pg=PR5\&ots=DgETlqkdOa\&sig=j5Q7XDOWKCg2XHyqJBBBPkH2DBQ\&red

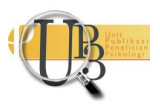


ir_esc $=\mathrm{y} \# \mathrm{v}=$ onepage $\& \mathrm{q} \& \mathrm{f}=$ false

Maryam, S. (2017). Strategi Coping: Teori Dan Sumberdayanya. Jurnal Konseling Andi Matappa, 1(2), 101-107.

Mayordomo-Rodríguez, T., Meléndez-Moral, J. C., Viguer-Segui, P., \& Sales-Galán, A. (2014). Coping Strategies as Predictors of Well-Being in Youth Adult. Social Indicators Research 2014 122:2, 122(2), 479-489. https://doi.org/10.1007/S11205-014-0689-4

Nadi, H. I. ., Kurniawati, N. D., \& Mariyanti, H. (2018). Dukungan sosial dan motivasi berhubungan dengan kepatuhan pembatasan asupan cairan pada pasien penyakit ginjal kronik yang menjalani hemodialisis. Critical Medical and Surgical Nursing Journal, 6(2), 8-14. https://doi.org/10.20473/CMSNJ.V6I2.12828

Neuman, W. L. (2007). Basics of social research: Qualitative and Quantitative Approaches (2ed.). Boston: Pearson Education, Inc.

Nurjanah, S. (2020). Gangguan Mental Emosional Pada Klien Pandemi Covid 19 di Rumah Karantina. Journal Ilmu Keperawatan Jiwa, 3(3), 329-334.

Poerwandari, K. (2013). Pendekatan kualitatif untuk penelitian perilaku manusia. Depok: Lembaga Pengembangan Sarana Pengukuran dan Pendidikan Psikologi (LPSP3). https://scholar.google.com/scholar?hl=en\&as_sdt=0\%2C5\&q=poerwandari+2013+pendekatan+ kualitatif+untuk+penelitian+perilaku+manusia\&btnG=

Rahmania, F. A., \& Tasaufi, M. N. F. (2020). Terapi Kelompok Suportif untuk Menurunkan Quarter-Life Crisis pada Individu Dewasa Awal di Masa Pandemi Covid-19. Psisula: Prosiding Berkala Psikologi, 2(0), 1-16. https://doi.org/10.30659/PSISULA.V2I0.13061

Santrock, J. W. (2012). Life-span development, edisi ketigabelas. Jakarta: Erlangga.

Sun, N., Wei, L., Wang, H., Wang, X., Gao, M., Hu, X., \& Shi, S. (2021). Qualitative study of the psychological experience of COVID-19 patients during hospitalization. Journal of Affective Disorders, 278, 15-22. https://doi.org/10.1016/J.JAD.2020.08.040

Supriatin. (2021). Data Kemenkes per 9 Februari 2021: 47,3\% Pasien Meninggal Covid-19 Adalah Lansia I merdeka.com. 09 Februari. https://www.merdeka.com/peristiwa/data-kemenkes-per-9februari-2021-551555-lansia-meninggal-karena-covid-19.html

Taylor, S. E. (2015). Health Psychology (9th ed.). New York: McGraw-Hill Education. https://lib.hpu.edu.vn/handle/123456789/32526

Zandifar, A., Badrfam, R., Yazdani, S., Arzaghi, S. M., Rahimi, F., Ghasemi, S., Khamisabadi, S., Khonsari, N. M., \& Qorbani, M. (2020). Prevalence and severity of depression, anxiety, stress and perceived stress in hospitalized patients with COVID-19. Journal of Diabetes \& Metabolic Disorders 2020 19:2, 19(2), 1431-1438. https://doi.org/10.1007/S40200-020-00667-1 